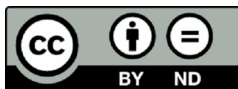

Acta Poloniae Historica

112,2015

PL ISSN 0001-6892

\title{
Antoni Grabowski
}

Warsaw

\section{FROM CASTRATION TO MISOGYNY. THE MEANING OF LIUDPRAND OF CREMONA'S HUMOUR*}

\begin{abstract}
Liudprand of Cremona is one of the most interesting authors of the tenth century. He is well known for his description of the Byzantine court and also for his jokes in Antapodosis - a first chronicle of Europe. Based on these tales, he is treated by scholars as a prime example of medieval misogyny. Lately the more political view of these narrations emerged, but still women in Liudprand's works are seen mainly as victims. This essay shows that this view is wrong and that there is much more to be found in the text. Through Liudprand's jokes emerges a much more complicated view of the position and role of woman in the society. To see this, the stories have to be put in the context of the tenth-century society.
\end{abstract}

Keywords: gender, sex, violence, nudity, castration, humour

Liudprand of Cremona's works are one of our main sources for the tenth century. ${ }^{1} \mathrm{He}$ is famous mostly thanks to the account of his embassy to Constantinople which took place in 968. While this

* I would like to thank Aneta Pieniądz, Przemysław Tyszka and members of Jacek Banaszkiewicz's seminar at the University of Warsaw, as well as the Acta Poloniae Historica's reviewer and editors, for their valuable comments and help in the improvement of this article. I am also indebted to Magdalena Kozłowska, Edyta Pętkowska and Falkon 2011, 2014, Polcon 2013.

${ }^{1}$ On Liudprand, see the following, still valuable, studies: Jon N. Sutherland, Liudprand of Cremona, Bishop, Diplomat, Historian: Studies of the Man and his Age (Biblioteca degli 'Studi medievali', 14, Spoleto, 1988); of the recent scholarship, see Vito Sivo, 'Studi recenti su Liutprando di Cremona', Quaderni medievali, 44 (1997), 214-25; Antoni Grabowski, 'Ostatnie studia o Liudprandzie z Cremony', Studia Źródtoznawcze, li (2013), 93-103. The edition of Liudprand's work used here is Liudprandus Cremonensis, Opera omnia, ed. Paolo Chiesa (Corpus Christianorum, Continuatio Mediaevalis, 156, Turnhout, 1998). Recently, two updated versions of Chiesa's text have been published - one accommodated with the French 
account prevails as far as the scholars' view of Liudprand is concerned, there is also a second topic of interest: his raunchy tales about Italian women and men, to be found in his chronicle of Europe: Antapodosis. In this article, I want to make a closer look at some of them. I want to put them in a proper perspective and explain the context in which they were written. While by some they are considered misogynistic; when read closely, it turns out that the stories are not directed against women. They are rooted in Liudprand's political aims. It is obvious that from today's perspective Liudprand has to be considered a misogynist, but it is wrong to see his stories through such glasses. Especially that, contrary to some views, Liudprand proved able to write also some extremely positive things about his heroines.

The stories that are to be discussed here were so shocking for the nineteenth-century audience that the German translation of Liudprand's works was heavily censored. ${ }^{2}$ Carl Dändliker and Johann Müller, authors of a commentary to Liudprand's all-then-known texts wrote that some of his stories represented something that should be called 'a pathetic humour'. ${ }^{3}$ While for many scholars they were repulsive, in comparison with other scandalous texts they are rather tame, especially if compared to the Suetonius' description of Tiberius's court. ${ }^{4}$ Liudprand's tales are hardly close to being pornographic, but such extreme critical view is still dominant. Aneta Pieniądz in one of her articles summarised various views on Liudprand, who "was presented as one of the most repulsive exponents of medieval Church's

translation: Liudprand de Crémone, Oeuvres, trans. François Bougard (Sources d'histoire médiévale, 41, Paris, 2015), and the other with the Italian translation: Liutprando, Antapodosis, trans. Paolo Chiesa (Scrittori greci e latini, Milano, 2015). All quotations in English from Liudprand's text are from The complete works of Liudprand of Cremona, trans. Paolo Squatriti (Washington, DC, 2007). References to Liudprand's text - both Antapodosis and Relatio de legatione Constantinopolitana are herein reduced to the title of his work and the indication of Book/Chapter. When there is a direct quote, then page of Chiesa's 1998 edition and Squatriti's translation's is added.

${ }^{2}$ Aus Liudprands Werken. Nach der Ausgabe der Monumenta Germaniae, trans. Karl von der Osten-Sacken, introduction Wilhelm Wattenbach (Berlin, 1853).

3 'Pathetischer Humor', Carl Dändliker and Johann J. Müller, Liudprand von Cremona und seine Quellen. Untersuchungen zur allgemeinen Geschichte (Untersuchungen zur mittleren Geschichte, 1, Leipzig, 1871), 175.

${ }^{4}$ Suetonius, Tiberius, c. 43-5, in Suetonius, Lives of the Caesars, trans. John C. Rolfe, i (Loeb Classical Library, 31, London, 1979), 352-6. 
misogynistic doctrine and embodied the collective obsession about women. His experiences show these sick emotions of the dominant part of male members of the society, which legitimised symbolic and physical violence toward the second sex. In this view the abused and mocked heroines of Liudprand's tales are pitiable and provoke solidarity to those victims of the repressive phallocentric system." ${ }^{5}$

Such opinion about Liudprand and his works, together with the fact that these tales are still funny and retain their humorous aspect even for modern audience, has made him into a popular subject in scholarly works concerned with sex and gender. Various authors used his texts as a basis for a discussion of the position of women in the tenth century. At the same time, the nature of these stories has made him an easy target for those looking for examples of medieval misogyny.

Not for everyone was Liudprand an example of clerical hate of women. In 1995 Philippe Buc wrote his votum separatum against claims of misogyny pushed against the author of Antapodosis. ${ }^{6}$ There he has shown that Liudprand's tales had a deeper meaning and that they are hardly against women per se. They target them not because of the author's misogyny but because of the demands of politics. Instead of an exemplary misogynist, Buc saw the author of Antapodosis as a propagandist. This could be seen when descriptions of Italian women have been compared to female members of Liudolfingian dynasty. The elevation and positive description of the representatives of the Ottonian family was meant as a proof of Liudprand's lack of misogyny. Buc's proposition has not been wholly accepted.

The point that has been agreed upon is the political aspect of Liudprand's work. It is clear that in his chronicle he consequently creates a division between the Saxon order and the Carolingian chaos. ${ }^{7}$ This does not make him a neutral author on the subject of women.

${ }^{5}$ Aneta Pieniądz, 'Wokół "Antapodosis" Liutpranda z Cremony', in Stanisław Rosik and Przemysław Wiszewski (eds.), Cor hominis: wielkie namiętności w dziejach, źródłach $i$ studiach nad przeszłościa (Wrocław, 2007), 29-35; for the present purpose, 33.

${ }^{6}$ Philippe Buc, 'Italian Hussies and German Matrons: Liutprand of Cremona on Dynastic Legitimation', Frühmittelalterliche Studien, xxix (1995), 207-25.

${ }^{7}$ Cristina La Rocca, 'Liutprando da Cremona e il paradigma femminile di dissoluzione dei Carolingi', in eadem (ed.), Agire da donna: modelli e pratiche di rappresentazione (secoli VI-X). Atti del convegno (Padova, 18-19 febbraio 2005) (Turnhout, 2006), 291-307; for the present purpose, 297. 
Most of the scholars still call him a misogynist and an enemy of women. This is mainly thanks to the influential text by Ross Balzaretti, entitled Liudprand of Cremona's sense of humour. ${ }^{8}$ In this article he examined Liudprand's jokes and fables concerning women. He came to a conclusion that the bishop of Cremona was a misogynist and a propagandist. His claim was based on the style of jokes found in Antapodosis. Women described there are laughable, when are active, while men are funny when passive. In Balzaretti's opinion, this clearly shows that the positive view of women of the Liudolfing house is independent upon Liudprand's own claims about women. Liudprand is, apparently, a thorough misogynist, and he demonstrates this even when expressing positive remarks on females. As has been said, Balzaretti's main proofs for such interpretation were the jokes and funny tales found in Antapodosis.

This was followed by Cristina La Rocca's reply to Buc's article. She has offered an interesting breakdown where the chapters of Liudprand's work are classed depending on whether they represent a positive, neutral, or negative image of females. ${ }^{9}$ On the basis of these and her analysis of the text, she comes to the conclusion that Liudprand was, clearly, a misogynist. ${ }^{10}$ La Rocca's argument is that for the author of Antapodosis active women were evil, or at least had to be seen in negative way. ${ }^{11}$

It is not my intention to argue whether Liudprand was a misogynist or not. By putting the jokes and funny tales about females from Antapodosis in a proper context, I instead seek to show that there is more in them. They have different meanings, and one of them features a positive female character.

I begin with one of Liudprand's most famous tales..$^{12}$ The central character is an unnamed woman, whose husband - a Greek soldier - was captured by Tedbald, one of Italian warlords of the tenth

${ }^{8}$ Ross Balzaretti, 'Liutprand of Cremona's Sense of Humour', in Guy Halsall (ed.), Humour, History and Politics in Late Antiquity and the Early Middle Ages (Cambridge and New York, 2002), 114-28.

${ }^{9}$ The story about a woman who saves her husband from castration (Antapodosis, IV.10) is not included there; La Rocca, 'Liutprando da Cremona', 295.

${ }^{10}$ Ibidem, 296.

${ }^{11}$ Ibidem, 307.

${ }^{12}$ Antapodosis, IV.9-10. 
century. ${ }^{13}$ Tedbald captured in one of his victories a group of men and boasted about this in a message sent to Greek strategos, who clearly was in command of the Empire's army. Tedbald claimed that he heard Byzantine Emperor loves nothing more than eunuchs. Therefore, the Italian will send him some of such men (that is, the castrated prisoners) and if God permits, he will send more in future. ${ }^{14}$ Liudprand proceeds with information that during another fight with Byzantine forces Tedbald captured a new group of soldiers. They were sent to a castle to be castrated there. Having heard this, a woman, the wife of one of those prisoners, moved by the fear for his members, came to the Italian commander's camp. ${ }^{15}$ The woman appears in the camp with her hair free and face mutilated with scratches made with fingernails. She was wooing and yelling there. This should be seen as an act similar to the lamentation, like the one expressed during funeral. ${ }^{16}$ This action prompted Tedbald, who came out to see what was happening, to ask her what the reason for such behaviour was. She accused

${ }^{13}$ Adolf Hofmeister marked him as one of Hugh's men, who acquired a position in the kingdom thanks to him; see idem, 'Markgrafen und Markgrafschaften im italienischen Königreich in der Zeit von Karl dem Grossen bis auf Otto den Grossen (774-962)', Mitteilungen des Instituts für Österreichische Geschichtsforschung. Ergänzungsband, vii (1907), 215-435; for the present purpose, 419-20. Chris Wickham marks Teobald (Tedbald) as a nephew of Hugh (most probably following Antapodosis, V.5, where Hugh calls Teobald 'nephew' nepos; Chiesa, 125; Squatriti, 173), Chris Wickham, Early Medieval Italy: Central Power and Local Society, 400-1000 (New Studies in Medieval History, London, 1981), 177-9.

${ }^{14}$ In a way this fits the Byzantine design. Tradition (at times) had it that most, if not all, eunuchs were spoils of war made from the captured enemies. This began to change in the tenth century; cf. Kathryn M. Ringrose, 'Reconfiguring the Prophet Daniel: Gender, Sanctity, and Castration in Byzantium', in Sharon A. Farmer and Carol Braun Pasternack (eds.), Gender and Difference in the Middle Ages (Minneapolis, 2003), 81.

${ }^{15}$ Liudprand in his text does not mention the camp: he just notes that the woman came to Tedbald's tent. As a side note, it is somewhat interesting what Isidore of Sevilla (Etymologiae, IX.iii.44) wrote about the word camp (castra): "A camp is where a soldier would be stationed. It is called a camp (castra) as if it were 'chaste' [castus], or because there sexual desire would be castrated [castrare] - for a woman never entered a camp" ("Castra sunt ubi miles steterit. Dicta autem castra quasi casta vel quod illic castraretur libido. Nam numquam his intererat mulier"), Isidore of Seville, Etymologiarum sive Originum libri XX, ed. Wallace M. Lindsay, i (London, 1911); Isidore of Seville, The Etymologies of Isidore of Seville, trans. Stephen A. Barney et al. (Cambridge and New York, 2006), 202.

${ }^{16}$ See n. 23 infra. 
him then of making a war against women. She said that they, at that time, did not bring their ancestry from the Amazons, but as they know nothing about weapons, they are much closer to the activities of Minerva. Tedbald strongly negated that he made a war against women with statement, that only mad men would do so, unless it was in "the time of the Amazons."17 Only after a longer passage, with some references to Virgil's works, it emerges that Tedbald's crime was the attempted castration of the prisoners. In the woman's reasoning, the penis, a source of pleasure and giver of hope for a child, was property of the wives. This explanation made the Tedbald's soldiers laugh and woman's husband was freed afterwards. Later on Tedbald sent a messenger asking her what he could do if the husband rebelled against him. The answer was clear: he can take the Greek's eyes, nose, legs and hands; the body's remainder is property of the woman.

According to Balzaretti this story presented a negative view about sexually active women whose were only interested in penises. ${ }^{18}$ On closer inspection there are some problems with his understanding of this joke.

At the story's beginning, in a historical summary, the readers is told about the conflicts between the Italian warlords and Byzantine forces. This grounds the story within a historical context and we learn a little bit about the conflict, but not in detail. ${ }^{19} \mathrm{~A}$ humorous element is present throughout the text. The message sent to the

17 "Amazonarum temporibus" Antapodosis IV.10; Chiesa, 102; Squatriti, 146.

${ }^{18}$ Balzaretti, 'Liutprand of Cremona's', 120. Interestingly, this understanding of Liudprand's tale corresponds with the late-medieval opinion on women who talk about such things as genitalia; see Lisa R. Perfetti, Women \& Laughter in Medieval Comic Literature (Ann Arbor, 2003), 71-3, 75. On the other hand, for Susan Tuchel, the story was made to show generosity of Tedbald, who, by the release of unharmed husband, is shown as a better man than the Byzantine Emperor; eadem, Kastration im Mittelalter (Studia humaniora, 30, Düsseldorf, 1998), 94.

${ }^{19}$ Steven Runciman, The Emperor Romanus Lecapenus and his Reign: A Study of Tenth-Century Byzantium, (Cambridge Paperback Library, Cambridge and New York, 1988), 191-3; Barbara M. Kreutz, Before the Normans: Southern Italy in the Ninth and Tenth Centuries (Philadelphia, 1991), 98-9; Karl Leyser, 'The Tenth Century in Byzantine-Western Relationships', in Derek Baker (ed.), Relations between East $\mathcal{E}$ West in the Middle Ages (Edinburgh, 1973), 29-63, here 56-7, n. 60; Vera von Falkenhausen, Untersuchungen über die byzantinische Herrschaft in Süditalien vom 9. bis ins 11. Jahrhundert (Wiesbaden, 1967), 32-3, 78-9, 120-1. 
strategos telling him that Tedbald has heard about Emperor's love of precious eunuchs and that therefore he will send him a few, and more, with God's help, is in fact one of the more bizarre jokes Liudprand ever wrote. At the same time, this is a very well designed political attack on the Eastern Empire. Eunuchs are a staple of Liudprand's attacks on Constantinople. They appear many times in his later Relatio de legatione Constantinopolitana, where he plays on the idea that it is shameful for the Italians that the Emperor sends a eunuch as a commander of his troops. ${ }^{20}$

In Tedbald's speech Liudprand reminds his readers about the association between Byzantium and castrated men, but this is only an introduction to a larger joke. It retains the anti-Byzantine vibe but its subject is broader. It is built on a woman's reaction to the endangerment of her husband with castration. The first point at which laughter enters the story is after she has explained Tedbald that what he does is, in fact, fighting against women. To understand what is funny about it, one has to point out what the entourage of Tedbald's laughed at. In Balzaretti's interpretation, the funny element is the woman, and she is the laughed-at object. ${ }^{21} \mathrm{He}$ even notes that in the way Liudprand constructs the story, the situation is being made such that "she might be an Amazon". ${ }^{22}$ It is not only difficult to see her as an Amazon, but this notion shows us even more: Balzaretti,

${ }^{20}$ Relatio de legatione Constantinopolitana, c. 29; cf. Shaun Tougher, The Eunuch in Byzantine History and Society (London and New York, 2008), 103 and n. 69. See also Leo the Deacon's (I.2) information on Constantine Gongyles, who "was a eunuch of the bedchamber, an effeminate fellow from Paphlagonia", and was an army commander whom Leo criticized for his ineptitude and cowardice; Leonis diaconi Caloënsis historiae libri decem, ed. by Charles B. Hase (Corpus Scriptorum Historiae Byzantinae, 11, Bonn, 1828), 7; Leo the Deacon, The History of Leo the Deacon: Byzantine Military Expansion in the Tenth Century, trans. Denis F. Sullivan and Alice-Mary Maffry Talbot (Washington, DC, 2005), 59; see also Leonis Diaconi, III.3-5 (pp. 38-43); a praise of someone, that he is quite skilled even though he is a eunuch is seen in Leonis Diaconi, IV.7-8 (pp. 65-8), V.4 (p. 81). Liudprand also wrote about a certain eunuch - a commander of the Byzantine soldiers - who was captured by the Saracens. Afterwards they executed all his men, but decided not to kill him explaining that it would be disrespectful for them to kill a eunuch (Relatio de legatione Constantinopolitana, c. 43); cf. Tougher, The Eunuch, 116, n. 178, where stated that the commander in question was patrikios Niketas, brother of the protovestiarios Michael.

${ }^{21}$ Balzaretti, 'Liutprand of Cremona's', 120.

22 Ibidem. 
apparently, did not actually get the joke (humour, as he aptly mentions, is a difficult thing to comprehend ${ }^{23}$ ).

While, as I understand, Balzaretti implies that the entourage of Tedbald might have perceived the wife as an Amazon, there is a problem with such interpretation. Her behaviour, with her loose hair and blood-stained face, is not a warrior's one. She is a grieving woman. ${ }^{24}$ She is much closer to the women of the funeral procession. It is obvious that an Amazon would, in such a situation, have behaved differently; first of all, she would have stood proud with a sword and would actually have attacked those who had endangered her well-being. She mentions the Amazons in her speech directed at Tedbald, but in her statements she is nowhere near to be one. On the contrary, her mention of warrior women is a form of attack on Tedbald. She first states that it is a great calamity to wage a war against unarmed women that are not descendants of Amazons, but are behaving as regular (tenth-century) women. It fits the concept that war is man's job. Tedbald's own words about fighting Amazons but not women put him in a difficult position. Fighting the former was acceptable, and this is about a conflict appearing in many stories about the origins of the society. However, in the times of Tedbald the situation changed, such conflicts did not happen and, as he asserts, only a madman would fight against women. Therefore, as the story shows that his actions are waged against women, he in fact explicitly calls himself a madman.

The woman's explanation that the man's penis is actually in the possession of his wife does not show her fixation on that part of human body. Her reasons are clear if the medieval society's ideas about marriage, sexual intercourse, and pleasure are taken into account. ${ }^{25}$ The ability to have children was in many ways a great

23 Ibidem, 116-17.

${ }^{24}$ See Balzaretti, 'Liutprand of Cremona's', 119-20; Robert Bartlett, 'Symbolic Meanings of Hair in the Middle Ages', Transactions of the Royal Historical Society, ser. 6, iv (1994), 43-60, here 53-6.

25 Taking pleasure from sexual intercourse was a problem if the activity was not regulated. Therefore, the society was openly criticised wherever women were ruling the bed. Cf. Jacek Banaszkiewicz, "Wątek "ujarzmienia” kobiet jako składnik tradycji o narodzinach społeczności cywilizowanej. Przekazy "słowiańskie” wcześniejszego średniowiecza', in Roman Michałowski et al. (eds.), Człowiek w społeczeństwie średniowiecznym. Konferencja naukowa (Warszawa, 1997), 27-44; for the 
asset to woman. The infertile woman was unwelcome in the secular society; the more children a woman had, the better. This being the case, how could a woman attain her position in the society in case her husband has ceased to be able to procreate? Later on, in the twelfth and thirteenth century, Canonists quite explicitly stated that one of the two objectives of a marriage was to beget a progeny. ${ }^{26}$ This acceptance of procreation can also be seen when we look at various texts on prohibited sexual acts, where the general rule is that the legit - even if still seen as sinful - were the ones that ended in childbearing. Any other option was considered dangerous or sinful. ${ }^{27}$ Additionally, in the Merovingian times, there was a notion retained from ancient time that the difference between a wife and a prostitute lay in the reasons for their sexual activity. If it was for pleasure, then the woman was the latter, and if for procreation, the former. Inability to bear children was seen as one of the possible reasons (but not always, and not by everyone as valid) for a man to divorce a woman at that time. ${ }^{28}$

present purpose, 37-8 (rpt. in idem, Takie sobie średniowieczne bajeczki [Kraków, 2012], 309-10).

${ }^{26}$ Rudolf Weigand, 'Die Lehre der Kanonisten des 12. und 13. Jahrhunderts von den Ehezwecken', in Giuseppe Forchielli and Alfons M. Stickler (eds.), Collectanea Stephan Kuttner II (Studia Gratiana, 12, Bologna, 1967), 443-78; rpt., with retained pagination, in idem, Liebe und Ehe im Mittelalter (Bibliotheca eruditorum, 7, Goldbach, 1998), 447-9. This does not mean that the care about the need to have children was universally accepted in Church; through the history, different views on the subject have appeared.

${ }^{27}$ Karma Lochrie, 'Heterosexuality', in Ruth Evans (ed.), A Cultural History of Sexuality in the Middle Ages (A Cultural History of Sexuality, 2, Oxford et al., 2011), 37-56, here 41.

${ }^{28}$ Suzanne F. Wemple, Women in Frankish Society: Marriage and the Cloister, 500 to 900 (Philadelphia, 1985), 41, 42; Dennis H. Green, Women and Marriage in German Medieval Romance (Cambridge and New York, 2009), 25-7. See also Patricia Skinner, “The Light of my Eyes": Medieval Motherhood in the Mediterranean', Women's History Review, vi, 3 (1997), 391-410. Furthermore, Clarissa W. Atkinson notes in her book that sometimes quite a different attitude to motherhood compared to the one herein discussed was emphatically expressed; certain Christian texts claimed that motherhood and sainthood were excluding each other, so being a mother was not seen as a positive thing (p. 66-7). Nevertheless, this is an extremely complex and difficult subject, as seen in examples of saint mothers (p. 77). Eadem, Oldest Vocation: Christian Motherhood in the Middle Ages (Ithaca, NY, 1994). Divorce/dissolution of marriage was not an easy thing to achieve, even for a person of power. Lothar II and Teutberga's case is a good example: the main point there was about being the queen's vice (incest). For an in-depth discussion 
On the other hand, there is some evidence that in the ninth century a woman had the right to remarry if her husband was an impotent ${ }^{29}$, and such view is not only seen in Anglo-Saxon penitentials; it was later expressed by Burchard of Worms, who summarised the previous findings on the subject. ${ }^{30}$ It goes without question that castrated man could be seen as impotent. ${ }^{31}$ Also Rather of Verona, as Balzaretti noted in different article, claimed that only a marriage conceived to

of this case, see: Karl J. Heidecker, The Divorce of Lothar II: Christian Marriage and Political Power in the Carolingian World, trans. Tanis M. Guest (Conjunctions of religion and power in the medieval past, Ithaca, NY, 2010). See also Stuart Airlie, 'Private Bodies and the Body Politic in the Divorce Case of Lothar II', Past \& Present, 161 (1998), 3-38; Abigail Firey, A Contrite Heart Prosecution and Redemption in the Carolingian Empire (Leiden and Boston, MA, 2009), 9-60.

${ }^{29}$ Wemple, Women in Frankish Society, 78; Jo Ann McNamara and Suzanne F. Wemple, 'Marriage and Divorce in the Frankish Kingdom', in Brenda Bolton and Susan Mosher Stuard (eds.), Women in Medieval Society (Philadelphia, 1989), 95-124; for the present purpose, 103; Heidecker, The Divorce of Lothar II, 17-18. On this point, see also James A. Brundage, Law, Sex, and Christian Society in Medieval Europe (Chicago, 1987), 144-5. This marked a change compared to the time of St Augustine of Hippo, who spoke against divorce in such cases; see: St Augustinus, 'De bono coniugali', in idem, Opera, ed. Joseph Zycha (Corpus Scriptorum Ecclesiasticorum Latinorum, 41, Leipzig, Praha, and Wien, 1900), 185-231, c. 15, p. 209; cf. Juraj Kamas, The Separation of the Spouses with the Bond Remaining: Historical and Canonical Study with Ppastoral Applications (Tesi Gregoriana, 20, Roma, 1997), 57.

${ }^{30}$ One such is Theodore of Canterbury, Poenitentiale, c. 11 (PL 99, 934C); cf. Kamas, The separation, 75. As for Burchard, see Burchard of Worms, Decretum libri viginti, 9.40-1; 19.5 (PL 140, 821C; 967BC). For the later discussions of the problem, see Brundage, Law, 290-2, 376-8. It is also interesting to note that in the early Irish penitentials woman's inability to have children was not seen as viable reason for a divorce; cf. Penitential of Finnian, 41; Penitential of Cummean, II.28; Ludwig Bieler (ed.), The Irish Penitentials (Scriptores Latini Hiberniae, 5, Dublin, 1963), resp. 88-90 and 116). For more on this point, see Kamas, The separation, 74; Jack Goody, The Development of the Family and Marriage in Europe (Past and Present Publications, Cambridge and New York, 1983), 190.

${ }^{31}$ Cf. Irina Metzler's thoughts about this story by Liudprand: in her view, castration quite clearly made man disabled in the views of the society; eadem, A Social History of Disability in the Middle Ages: Cultural Considerations of Physical Impairment (Routledge Studies in Cultural History, 20, New York, 2013), 22. Castration lowered the social standing of a man, who was made infertile in a society where fertility was very important. To quote Przemysław Tyszka: "It deprived a man of sex in the social aspect", idem, 'Sexual Violence in the Early Medieval West', Acta Poloniae Historica, 104 (2011), 5-30; for the present purpose, 27. 
procreate was a positive thing. What is more, he was highly critical of other kinds of sexual activity. ${ }^{32}$ Similar notions were made by Atto of Verceli in his Expositio in epistola Pauli about Ad Corinthians 1, where he underlined that God ordered mankind to populate Earth. ${ }^{33}$ Such understanding of the meaning and role of marriage implied that marriage was made binding by a sexual intercourse. If husband and wife have never done it, then the marriage was invalid (never fulfilled). ${ }^{34}$ This does not mean that a wife of the soldier could divorce him if he was castrated; nevertheless, his acquired impotence is something that would have consequences for their marriage.

From the Carolingian time there also comes a more positive vision of motherhood in hagiography ${ }^{35}$ and additionally in the Later Life of Mathilde there is a notion that children were the God's gift. ${ }^{36}$ Children also could serve their mothers as a help in their old age and/or widowhood. In a way, they were the most valuable treasure for women. ${ }^{37}$

${ }^{32}$ Rather, Praeloquia, II, III.5-6, in Ratherius Veronensis, 'Praeloquiorum libri VI', in idem, Praeloquiorum libri VI; Phrenesis; Dialogus confessionalis; Exhortatio et preces, ed. by Peter L. D. Reid (Corpus Christianorum, 46A, Turnhout, 1984), 1-196, here 48-51; cf. Ross Balzaretti, 'Men and Sex in Tenth-Century Italy', in Dawn M. Hadley (ed.), Masculinity in medieval Europe (London and New York, 1999), 143-59; for the present purpose, 146-7.

${ }^{33}$ Atto of Vercelli, Epistola Prima ad Corinthios (PL 134, col. 349-50); Balzaretti, 'Men and Sex', 153.

${ }^{34}$ Lisa M. Bitel, Women in Early Medieval Europe, 400-1100 (Cambridge Medieval Textbooks, Cambridge and New York, 2002), 172. For a more cautious view of the role of intercourse in the setting up of marriage, see: David L. D'Avray, Medieval Marriage: Symbolism and Society (Oxford and New York, 2005), 168-99, esp. 178-9.

${ }^{35}$ Grzegorz Pac, 'Obraz małżeństwa w wybranych niemieckich źródłach hagiograficznych X i XI wieku', in Roman Michałowski (ed.), Kult świętych i ideat świętości w średniowieczu (Fasciculi Historici Novi, 11, Warszawa, 2011), 7-148; for the present purpose, 71-2.

36 'Vita Mathildis reginae posterior', ed. Bernd Schütte, in Die Lebensbeschreibungen der Königin Mathilde (MGH, Scriptores rerum Germanicarum in usum scholarum separatim editi, 66, Hannover, 1994), c. 2, 6, pp. 149, 155. Cf. Pac, 'Obraz małżeństwa', 74. It is telling in this specific context that prayers were said for Carolingian queens' wombs and their fertility during marriage celebrations and coronations; Stuart Airlie, 'Private Bodies', 20-1.

${ }^{37}$ Bitel, Women, 178. The importance of children is seen in the Life of St Rusticula (Vita S. Rusticulae), with the mother of the saint woman asking who would help Rusticula once she entered the monastic life: "Who will look after me in my old age, now that the one daughter I had is lost?" ("Quis nunc aetatem meam fovebit, unica quam habebam amissa?”); 'Vita Rusticulae sive Marciae abbatissae 
The social rank or acquired position of the children could be used by their mothers and the contact between mother and her children was not limited to the time before their own marriage. ${ }^{38}$ Liudprand himself noted this when he remarked that Bertha, Hugh of Arles's mother, had no sons with her husband Adalbert. Instead, she secretly took them off from other women. She did this so that she "might not lack sons with whose help she could acquire all the power of her husband." ${ }^{39}$ For woman at that time, having family was especially important, both from legal and economic reasons. ${ }^{40}$

Castration was also not a normal action. It was a special form of punishment. In Theitmar's Chronicon we can find a notion about how evil this was and that the one who castrates should make penitence for what he has done. ${ }^{41}$ The repulsion against castration

Arelatensis', ed. by Ernst Dümmler, in Passiones vitaeque sanctorum aevi Merovingici, ii (MGH, SRM, 4, Hannover and Leipzig, 1902), c. 5, p 342; translation after Janet L. Nelson, 'Queens as Jezebels: Brunhild and Balthild in Merovingian History', in eadem, Politics and Ritual in Early Medieval Europe (London and Ronceverte, WV, 1986), 1-48; for the present purpose, 3 . There was some controversy over the date the Life was written. See Pierre Riché, 'Note d'hagiographie mérovingienne: La Vita S. Rusticulae', Analecta Bollandiana, lxxii (1954), 369-77. Similar in tone and feel was Herchenfreda's letter to her son Desiderius, where she begged him to protect his own life, as after the murder of Rusticulus and death of Syagrius, he was her only son, 'Vita Desiderii Cadurcae urbis episcopi', ed. by Ernst Dümmler, in Passiones vitaeque sanctorum aevi Merovingici, ii, c. 11, p. 570; cf. Wemple, Women, 60. Care about children and family is emphasised also in Dhouda's work dedicated to her son William. For a survey of this subject (including possible sources in Germanic tradition) in her work, see introduction to the English translation, Dhouda, Handbook for her warrior son: Liber manualis, trans. Marcelle Thiebaux (Cambridge Medieval Classics, 8, Cambridge, 2007), 25-7. The appearance of the topic in Vita Rusticulae, letters in Vita Desiderii and in Dhouda's handbook show that the topic was not a one off occurrence.

${ }^{38}$ Wemple, Women, 60-1.

39 “... filii non deessent, quorum adiutorio omnem mariti sui potenciam possideret”, Antapodosis, III.47; Chiesa, 92; Squatriti, 136.

${ }^{40}$ Bitel, Women, 161. Patricia Skinner notes that it was easy to adopt a son in the Mediterranean, and sometimes exchange of money was part of the process. But what is important here, the clear aim of most of such proceedings, was to acquire help in the old age. Sometimes these children were 'bought' for a time until their new parents die (Skinner, "'The light of my eyes"', 399-400), see also the duties of children towards parents and especially mothers, ibidem, 400.

${ }^{41}$ Thietmari Merseburgensis Episcopi Chronicon, ed. Robert Holtzmann (MGH, SRG, N.S., IX, Berlin, 1935), II, 40 (25), pp. 88-9. 
dated to quite an old time not only in Western Europe; it was also criticised, to an extent, in the East of Europe. In 97 AD there was a decision of a Roman senate, later included in Justinian Digesta, prohibiting castration of owned slave and the punishment for it was fine of half of wealth. ${ }^{42}$ Even in the Byzantine Empire a regulation against making eunuchs existed, and was reinforced by Pope Leo VI in the beginning of the tenth century. ${ }^{43}$ In late-medieval Western Europe, castration might have been a punishment for various crimes, such as rape, homosexuality and even, in a single case, bigamy. ${ }^{44}$

42 Justinian Digest, 48.8.6, in Digesta seu pandectae Iustiniani Augusti, ed. by Theodor Mommsen and Paul Krueger, ii (Berlin, 1870), 820. This law was later repeated by Hadrian (Digest 48.8 .4 , p. 820 ), who strengthened the severity of the punishment. There, the doctor (medicus) who had performed the operation was sentenced to death along with those who willingly asked to be castrated. These laws were not new ideas: on the contrary, they followed up a long-lasting process of regulating and forbidding of castration, which took place during the early Empire period. On these regulations and its consequences, see, for instance, Ra'anan Abusch, 'Negotiating Difference: Genital Mutilation in Roman Slave Law and the History of the Bar Kokhba Revolt', in Peter Schafer (ed.), The Bar Kokhba War Reconsidered: New Perspectives on the Second Jewish Revolt against Rome (Texts and Studies in Ancient Judaism, 100, Tübingen, 2003), 71-91; for the present purpose, 74-80. These regulations were not always observed; there are many examples of castration of Roman citizens made after these legislations were announced. See Shaun F. Tougher, 'Byzantine Eunuchs: An Overview, with Special Reference to their Creation and Origin', in Liz James (ed.), Women, Men, and Eunuchs: Gender in Byzantium (London and New York, 1997), 168-84, here 178-9. See also Przemysław Tyszka, The Human Body in Barbarian Laws, c. 500 - c. 800: Corpus Hominis as a Cultural Category, trans. Guy R. Torr (Frankfurt am Main and New York, 2014), esp. 78.

${ }^{43}$ Mathew Stephen Kuefler, 'Castration and Eunuchism in the Middle Ages', in Vern L. Bullough and James A. Brundage (eds.), Handbook of Medieval Sexuality (Garland Reference Library of the Humanities, 1696, New York, 1996), 279-306; for the present purpose, 287. There was also great animosity toward eunuchs expressed since the late Antiquity and retained in the Byzantium. The antagonism towards them was so strong that a text was written in their defence against various accusations, such as corruption and sexual perversion; see Tougher, 'Byzantine eunuchs', 173-5, n. 45. Tougher later on expanded on this subject, including also the positive views on eunuchs; see his book: idem, The Eunuch, 96-109. Tougher also notes that Leo VI not only had eunuchs made of his subjects but also rendered castration for medical reasons legal; see idem, 'Byzantine eunuchs', 179. For the Western views on eunuchs in Byzantium (mainly based on Liudprand, but not limited to him), see idem, The eunuch, 115-18.

${ }^{44}$ Kuefler, 'Castration', 288. On the use of castration as a punishment in Byzantium see, e.g., Tougher, The Eunuch, 28. 
Among Normans it was an equivalent of death penalty for treason. ${ }^{45}$ A clear enmity towards castration existed also in the earlier Frankish laws. The Capitula legi Salicae addita puts forth the idea that even if made for medical purposes, castration was to be punished by fine. ${ }^{46}$ Therefore, it is clear that Tedbald's actions were out of the normal behaviour. ${ }^{47}$ They were wrong, and the wife shows that in the end they were targeted against women. Their situation was directly endangered by this act.

This view is also strengthened by what the woman in question says about the loot Tedbald has gathered. Sheep and cattle are standard trophies; it is part of a war. Her statement that it is not for them that she has come over is to show that what Tedbald wants to do to her husband is something extraordinary. If he was to make a normal war, with everything that can be expected because of it, then there would be no problem and she would have to accept everything whatever may be taking place. Such construction of the tale does not show a wife as a sex maniac, whilst Tedbald appears intolerably cruel.

Thus, it can be clearly said that Tedbald's men laugh not at the sex-oriented woman who thinks only about a penis; Liudprand many times takes note of her intelligence and wisdom, and the speech itself is evidence that he has made her into a positive character. What she said was a well-devised ploy meant to put Tedbald in a no choice situation. His claim that only a madman could wage war against women is put against him; she has proved that he is the one who wages it. The gathered people see it that way and laugh. They laugh at the well

${ }^{45}$ Klaus van Eickels, 'Gendered Violence: Castration and Blinding as Punishment for Treason in Normandy and Anglo-Norman England', Gender \& History, xvi, 3 (2004), 588-602, here 596.

${ }^{46}$ Capitula legi Salicae addita, LXXI $\$ 2$ (MGH, LL nat. Germ. 4.1, p. 241); Pactus legis Salicae, XXIX \$17 (MGH, LL nat. Germ. 4.1, p. 117), Lex Ribuaria 6, 28 (27) (MGH, LL nat. Germ. 3.2, pp. 76, 84), Kuefler, 'Castration', 301, n. 131. On barbarian laws in the context of castration, see: Tyszka, The Human Body, 129-30, 133. On the construction of these laws, see ibidem, 81-114. The amount to be paid for castration was similar to that charged for rape or other sexual violence against women, but these laws belonged to different groups. Castration was an attack on the body, while rape was related to the social crimes (prostitution, abduction, etc.). See Tyszka, 'Sexual Violence', 27-30.

${ }^{47}$ Cf. Antoni Grabowski, 'Liudprand of Cremona's Papa Monstrum: The Image of Pope John XII in the Historia Ottonis', Early Medieval Europe, xxiii, 1 (2015), 67-92; for the present purpose, 82-3. 
devised speech, as everyone must at least praise such a creation of a smart woman, but also at their lord who becomes a victim of his own words. This is why Tedbald had to release his prisoner: while Balzaretti saw it as a proof of his mercy ${ }^{48}$, in reality he was forced to do so by the situation. He could not refuse because the speech was made in such way that there was no place to say no. Wit, humour and intelligence were the weapons available to women in the society, in lieu of other means. ${ }^{49}$ Therefore, the wife in the story made use of this weaponry to save her husband.

Balzaretti also points at the bizarre answer the wife gives Tedbald's envoy when asked how her husband should be punished if he takes up arms again. The enumeration of parts and members he can cut off from his body is meant to show how sex-oriented and penis-focused the woman was. But, what did she actually say? "Those are his eyes", said she, "his nostrils, hands, and feet. If he needs it, let Tedbald remove what is his; but let him leave alone what is mine, I mean, of his humble servant." 50 This is a continuation of the joke. As Liudprand notes, she was aware that her first speech won her favour of Tedbald's people. Therefore, she needs to play the game to a funny end.

Liudprand also from time to time noted the strength and power some women held. For example, Theodora "was holding the monarchy of the city of Rome, and not in an unmanly way." 51 Women many times are mentioned as the ones that decide about politics. There, the wife of a soldier owns him in a way, and at the same time she

${ }^{48}$ Balzaretti, 'Liutprand of Cremona's', 119.

${ }^{49}$ Perfetti, Women E Laughter, 86-9.

50 "Oculi - inquit - sunt illi, nares, manus et pedes. Si hoc egerit, sibi quae sua sunt auferat; quae mea suae scilicet ancillulae, derelinquat", Antapodosi, IV.10; Chiesa, 102; Squatriti, 147.

51 "Romanae civitatis non inviriliter monarchiam obtinebat", Antapodosis, II.48; Chiesa, 54; Squatriti, 96. There is somewhat similar sentence in Historia Augusta about Zenobia, who ruled: "non mulibriter neque more femineo ... Zenobia Palmyrenis et orientalibus plerisque uiriliter imperante”, Gallieni DVO XIII.2, 5, in Histoire Auguste, iv, 2: Vies des deux Valériens et des deux Galliens, ed. Olivier Desbordes and Stéphane Ratti (Paris, 2002), 33. Josef Becker in his edition of Liudprand's work had to remark (in a footnote) to note that the statement of Theodora's rule is exaggerated ("Dieser Ausdruck ist übertrieben"), although he acknowledged her to be highly influential, Liudprand von Cremona, Die Werke Luidprands von Cremona, ed. Josef Becker (MGH, Scriptores rerum germanicarum in usum scholarum, 41, Hannover and Leipzig, 1915), 59, n. 1. 
calls herself 'a humble servant'. It rings the same bell as a quote from the film Labyrinth by Jim Henson (1986): "Love me, fear me, do what I say and I'll be your slave!" This is important because it shows that Liudprand was well aware about the irony of both the situation and a scene for the readers.

Antapodosis is not the only source from the tenth century that offers a description of a woman's reaction to a castration of her husband. In Chronicon Salernitanum there is a tale ${ }^{52}$ whose similarities to Liudprand's were noted by Gustavo Vinay ${ }^{53}$ and Massimo Oldoni. ${ }^{54}$ The plot is as follows: When the ruler of the Duchy of Benevento, Guy of Spoleto, was invited to come to the north, he decided to leave his lands to Guaimar, the ruler of Salerno. The decision was not popular with the people. When Guaimar entered the city, he was attacked at night by one of the city's leading men, and captured. His eyes were gouged and one of the soldiers was preparing to castrate him. When Guaimar's wife Idta realised what was going to happen, she jumped to the feet of Adelferius, a leader of the conspiracy, who ordered the mutilation of the captured prince. Crying, she screamed, begging him not to add additional evil to what he has done already. One of the soldiers named John carried her out, and the text is silent about what happened later. Not strangely, the modern historian writing about the situation decided that the danger of Guaimar's castration would not fit into a scholarly narrative, and left it out. ${ }^{55}$ While it is in many ways a bizarre situation, it is important that Idta wanted to save Guaimar's penis. While the context and the style of the narratives are different, as Liudprand makes a joke and the anonymous author of Chronicon Salernitanum writes a historical account, there is a shared idea to them. Castration is evil and, importantly, the wife has not only the right but also a good reason to protect her husband from it.

To better see that the story, with its figure of wife, has a different meaning than Balzaretti believes, it is vital to make a closer look on another Liudprand's tale: the one about Willa and her priestlet

${ }^{52}$ Chronicon Salernitanum. A Critical Edition with Studies on Literary and Historical Sources and on Language, ed. by Ulla Westerbergh (Acta Universitatis Stockholmiensis, Studia Latina Stockholmiensia, 3, Stockholm and Lund, 1956), c. 147 , pp. 155-6.

${ }^{53}$ Gustavo Vinay, Alto Medioevo latino: conversazioni e no (Napoli, 1978), 411.

${ }^{54}$ Massimo Oldoni, Anonimo salernitano del X secolo (Napoli, 1972), 24.

${ }^{55}$ Kreutz, Before the Normans, 66-7. 
Dominic. While Balzaretti notices the story, he would not describe it in detail. ${ }^{56}$ The narration here is actually a rather basic one. Willa, wife of Berengar II, has a priest Dominic at the court. He is, to quote: "short in stature, sooty in colour, crude, bristly, restless, rough, a barbarian, harsh, hairy, endowed with a tail, shameless, mad, rebellious, unfair." ${ }^{57}$ This long elaboration presents a vicious creature, rather than a priest. For Enza Collona, this description of appearance of Dominic was made to mark him as a morally wrong person, according to the idea that the person's appearance shows his or her true nature. ${ }^{58}$

Willa, a shrewd woman, seduces that man and when Berengar is away, invites him to her bed. Everything proceeds without a problem, but a vigilant dog suddenly notices and bites Dominic, and afterwards howls and barks so loud that the whole court is awakened, and they capture the escaping priest. To save herself, Willa claims that he was going to see one of her maids; after Berengar returns, she uses various methods, including magic, to secure his love for her. The poor priest is sentenced to castration for his crime, and here is the point of the story: "Those, however, who made him a eunuch said that the mistress had loved him for a good reason, as he proved to carry a massive priapic weapons." ${ }^{59}$ Willa comes out from the affair free and unpunished. It is inclined that Berengar was either made infatuated with her thanks to the actions of 'diviners and witches', or it was his 'softness' that made him put the 'marital muzzle' on. ${ }^{60}$ It is thus clear that she is an evil

${ }^{56}$ Balzaretti, 'Liutprand of Cremona's', 121-2; Enza Colonna notes the similarity between the story of husband and wife and the one about Willa and Dominic, making it clear that the wife is not portrayed in a negative way; see eadem, 'Figure femminili in Liutprando da Cremona', Quaderni medievali, 14 (1982), 29-60; for the present purpose, 43-4; see also 53-4. On the problem of men of cloth and castration, see also Tuchel, Kastration im Mittelalter, 108-13.

57 “... statura brevem, colore fuligineum, rusticum, setigerum, indocilem, agrestem, barbarum, durum, villosum, cauditum, petulcum, insanum, rebellem, iniquum", Antapodosis, V.32; Chiesa, 143; Squatriti, 193.

${ }_{58}$ Colonna, 'Figure femminili', 55 and n. 26.

59 "Dixerunt autem qui eum eunuchizaverun, quod merito illum domina amaret, quem priapeia portare arma constare", Antapodosis, V.32; Chiesa, 143; Squatriti, 194.

60 "... aruspices maleficosque ... molicie ... maritali ... ora capistro", Antapodosis, V.32, 143; Squatriti, 194. This is a pretty interesting translation by Squatriti. It is difficult to say why he has altered the gender of those malefici whom Willa asked for help, as the word denotes a male magician. The previous English translation, made by F. A. Wright, uses here a different word: 'sorcerers', which clearly 
character in the story and that her husband is weak. She is so evil that she uses magic, which is a sin in itself $f^{61}$, to achieve her goals. Liudprand makes of her a character of the worst sort possible.

In both stories penis and castration are central elements of the narrative, but the usage of them shows considerable differences. Both women seek pleasure and see penis as a way to achieve it, but Willa chooses her lover, a disgusting creature, because his member is big. The soldier's wife wants to save the penis to have children, secure herself in the society, and protect her husband from mutilation. The story about Willa is quite clearly a play on various concepts of womanhood and it puts woman in a position of sex-oriented creature. Liudprand uses the stereotypes to attack Willa. ${ }^{62}$ It is difficult to say whether it was also a way to accuse Berengar of some shortcomings in the department ${ }^{63}$, as it might only be a misinterpretation of the more basic joke. Still, it is an instance of defamation of the Italian ruler through the use of debauchery of his wife, as Caesar was meant to say that his "wife ought not even to be under suspicion." 64

Balzaretti in his article notes also the famous story about Willa, the wife of Hugh of Arles's brother, her husband Boso and his precious belt. According to Balzaretti, it also brings an anti-women message. It is one of the most popular stories written by Liudprand; Jonathan Jarret, for that matter, remarks in his exquisite and popular medievalist

is a better choice; Liudprand, The Works of Liudprand of Cremona, trans. Frederick A. Wright (London and New York, 1930), 200; cf. Bougard's 'sorciers', in Liudprand de Crémone, Oeuvres, 321, and Chiesa's 'maghi', in Liutprando, Antapodosis, 363.

${ }^{61}$ It was wrong not only to make magic and participate in other such practices, but even consulting a diviner was seen as wrong. Burchard of Worms, Decretum libri viginti, 19.5 (140, 960C). Burchard of Worms also remarks that the belief whereby some women can through their magical arts change hate into love and influence man's mind is a sin, and he even gives examples of some of such activities (ibidem, 961D, 973A, 974A, C). For a general discussion of the banning of magic, see Richard Kieckhefer, Magic in the Middle Ages (Cambridge Medieval Textbooks, Cambridge and New York, 1989), 177-80, 183-5; and, Catherine Rider, Magic and Impotence in the Middle Ages (Oxford and New York, 2006), 29-38.

${ }_{62}$ According to La Rocca, Liudprand might have been inspired by Procopius's Secret History in his attacks on Willa, Berengar II's wife; see La Rocca, 'Liutprando da Cremona', 298.

${ }^{63}$ As Balzaretti winks; idem, 'Liutprand of Cremona's', 121-2.

${ }^{64}$ Plutarchus, 'Caesar' (X.6), in idem, Lives, vii, trans. Bernadotte Perrin (Loeb Classical Library, 99, Cambridge, MA, 1919), 441-609; for the present purpose, 466-7. 
blog that he has never heard a lecture about the Bishop of Cremona that would not mention it. ${ }^{65}$

The story begins with King Hugh of Arles's discovery that his own brother, upon Willa's instigation, was conspiring against him. The ruler then sent him into a prison. While it was done, he remembered that Boso had a precious belt "which glittered with the splendour of many precious gems." ${ }^{\prime 66}$ Such a piece of jewellery was being sought by many. We need to remember that the belt had a special meaning and importance in that society. It was a symbol, an ornament of power. Enriched by jewels and made of precious metals, belt manifested the strength of its wearer. Belts were owned by nobles, and the descriptions of what they looked like, though regrettably limited to few generic words, appear a big deal in various texts. As Chrisitna La Rocca and Luigi Provero noted, Liudprand was well aware of the importance of this symbol. He used it a lot throughout Antapodosis, where the belt could be a means of identification of the noble. ${ }^{67}$

The one owned by Boso was of exceptional quality. Therefore, Hugh sent his men into the home of Boso, ordering them to bring the belt to him. They did as ordered and searched the place, but could not find the belt. Having heard that there was a problem, the king ordered them to search the horse and other things owned by Willa, while she was expelled from Italy to Burgundy. They were to search everywhere and if they still could not find it, they were told to strip Willa, as Hugh knew how greedy she was. So, after yet another failure, they moved their attention to Boso's wife. While her clothes were pulled off, none of the men looked at her, as it was most improper to do so. Still, there was no sign of the belt. It seemed that the effort was pointless, but there was one servant who displayed no such noble reactions. As he looked at Willa, he noticed something. It was a "string hanging below the sphere of her buttocks." 68

$65<$ http://tenthmedieval.wordpress.com/2010/07/27/leeds-2010-report-i/> [Accessed: Feb. 4, 2016].

66 "... qui multarum et pretiosarum splendebat nitore gemmarum", Antapodosis, IV.12; Chiesa, 103; Squatriti, 148.

${ }^{67}$ Luigi Provero and Cristina La Rocca, 'The Dead and Their Gifts. The Will of Eberhard, Count of Friuli, and His Wife Gisela, Daughter of Louis the Pious (863-864)', in Frans Theuws and Janet L. Nelson (eds.), Rituals of Power: from Late Antiquity to the Early Middle Ages (Leiden et al., 2000), 225-80, here 251-2.

68 “... secus natium speroiden vidit dependere corrigiam", Antapodosis, IV.12; Chiesa, 103; Squatriti, 148. 
Upon seeing that, the man pulled the string and the belt, to Willa's cries of shame, fell to the ground, coming out of her vagina. ${ }^{69}$ While the poor woman cried, the servant made a short, happy in tone, speech. He stated that he would be the "happiest of all men if my wife bore me just two such children." ${ }^{70} \mathrm{He}$ would even send a message to the Byzantine Emperor, who reportedly liked tales about such children.

This is followed by a short poem ${ }^{71}$ : the servant asks the poor woman why she "hid gold in the dark" and "the gems in your body."72 He then asks her not to hide such children. After this exclamation, one of the men present there hits the servant to punish him for his disrespectful words. ${ }^{73}$ The poem is followed by a short finale to the tale. Liudprand notes that the belt was sent to the king, and Willa deported to her exile in Burgundy. The last sentence of this description reads:

It seems uncertain to me who acted more basely: the one who hid it or the one who ordered the search; it is however clear that both were inspired by a great greed for gold and gems. ${ }^{74}$

${ }^{69}$ This bizarre story, where woman hid an expensive Lombard-style belt in her private parts, was looked upon to by many scholars. Sometimes it led to a strange conclusion. For example, Jon N. Sutherland claims that Liudprand coined the whole tale, as it was impossible anatomically for a woman to hid the belt in the like manner (because of its weight and decoration with jewels); idem, Liudprand of Cremona, 19-20. Aneta Pieniądz correctly noted that the place of hiding the belt - the most precious symbol of the power and riches of the noble, also means an attack on Boso; eadem, 'Kobieta, honor i polityka we wczesnym średniowieczu', in Agnieszka Bartoszewicz et al. (eds.), Świat średniowiecza (Warszawa, 2010), 408-24; for the present purpose, 420; Philippe Buc, The Dangers of Ritual: Between Early Medieval Texts and Social Scientific Theory (Princeton, 2001), 20.

70 "... immo omnibus feliciorem, si tales saltem duos uxor mea mihi pareret natos", Antapodosis, IV.12; Chiesa, 104; Squatriti, 149.

${ }^{71}$ Enza Colonna, Le poesie di Liutprando di Cremona: commento tra testo e contesto (Bari, 1996), 153-9.

72 "Aurum quod condere caecis ... gemmas in corpore condis", Antapodosis, IV.12; Chiesa, 104; Squatriti, 149.

${ }^{73}$ Colonna notes that as the servant (who takes up the belt) is a lower-class man, he was able to act in such a despicable way and cast harsh words at Willa; eadem, 'Figure femminili', 53-4.

74 "Utrum tamen quae abscondit aut qui eô inquirere iussit foedius egerit, michi quidem videtur amphibolum; liquet tamen quod uterque nimia sit auri gemmarumque cupidine animates", Antapodosis, IV.12; Chiesa, 104; Squatriti, 149. 
Robert Levine remarks that this tale should be seen in the context of the king's legitimacy. Willa's actions mark her uncleanness (it being implied that the other Italian noble women were so as well). In this way Liudprand wanted to exclude the claims made by kings of Italy with respect to the Carolingian ancestry. ${ }^{75}$ Quite a different view has been proposed by Aneta Pieniądz. Her studies perceive the whole tale as a realistic representation of what happened with Willa. Therefore, the actions of King Hugh were meant to humiliate the wife of his brother - a political enemy. Liudprand would thus be an author who gives us a realistic picture of the situation; in another scenario, he would write a tale to show us the punishment of Willa. ${ }^{76}$ Balzaretti, on the other hand, concentrates not on the meaning of the story but limits himself to the statement that the whole tale is misogynistic. He focuses on the poor wife of Boso and cuts the king's actions out from the picture. ${ }^{77}$ The last line of Liudprand's text appears in the passage he cites, but remains unrecognised.

This humorous tale is clearly misogynistic. ${ }^{78}$ Yet, there are things that have to be added to make the picture complete. Liudprand is well known for his hatred of Queen Willa and King Berengar II. The Willa from the story about the belt was actually a mother of that Italian queen. Therefore, it is clear that the tale, as Levine proposed, should be seen in a political context. Nevertheless, it would be wrong to limit the story to a discussion of the improper parentage of Berengar II's wife. There is more here than meets the eye. Liudprand equals

${ }^{75}$ On the importance of women in the context of the rights to rule and relationships in Liudprand's chronicle, see also Tiziana Lazzari, 'La rappresentazione dei legami di parentela e il ruolo delle donne nell'alta aristocrazia del Regno italico (secc. IX-X): l'esempio di Berta di Toscana', in La Rocca (ed.), Agire da donna, 129-49. Recently, Giacomo Vignodelli has convincingly argued why it was so important for Liudprand to attack the legitimacy of both Willas; see Giacomo Vignodelli, 'Imperial Blood: Liutprand of Cremona and the Carolingian Descent of King Adalbert of Italy' (presented at the International Medieval Congress, Leeds, UK, 2014). See also Robert Levine, 'Liudprand of Cremona: History and Debasement in the Tenth Century', Mittellateinisches Jahrbuch, xxvi (1991), 70-84; also published by Levine on his own webpage, <http://people.bu.edu/bobl/liud.htm> [Accessed: Feb. 4, 2016].

${ }^{76}$ Pieniądz, 'Kobieta', 418-24.

77 Balzaretti, 'Liutprand of Cremona's', 120-1.

${ }^{78}$ Aneta Pieniądz says that to her mind, Liudprand did not see this tale as a joke, or as a humorous narrative; see eadem, 'Wokół "Antapodosis"', 34. 
the actions of Hugh with those of his brother's wife. Moreover, apart from the Italian king being driven in his doings by greed, he would not show a hint of mercy throughout the story. There is no sign of forgiveness made toward his brother. This is quite a big contrast when compared to the description of Otto - whose elevation was the aim of whole Antapodosis ${ }^{79}$ - and his relations with his brother Henry ${ }^{80}$ Hugh will not stop or withdraw whenever he hopes to acquire gold and gems. While Willa was humiliated publicly, it was done not because the king's men wanted to do so. They were ordered by Hugh who told them that they should "strip her of all her clothes, lest she hide anything anywhere upon her." ${ }^{81}$ As remarked, his men did so but none looked at Willa as this was "filthy and unprecedented crime"! 82 Therefore, while the joke is at a woman, the wrongdoing is on the part of a man. This is a misogynistic tale, where in the end the male character is shown as evil and wrong. This becomes even clearer when compared to how Otto acted toward the wives of rebels. While it is implied that they had some role in the rebellion, ${ }^{83}$ none of them was in any way punished by Otto. The price they paid was the death of their husbands in a warfare. This shows clearly how wrong Hugh was because of greed and lack of mercy, where the latter was an important element of being a decent king.

To reinforce the argument, it is useful to look at Aneta Pieniądz's article on honour, discussing, among other things, a story from Chronicon Salernitanum about humiliation of a woman. ${ }^{84}$ The female character is the wife of a certain Adelchis. She was mistreated by his ruler, Sikard, who did that upon instigation of his own wife. Adelchis's wife was humiliated as she was forced to be seen by some camping soldiers with her skirt cut up to the knees. This spectacle

${ }^{79}$ On this point, see Antoni Grabowski, 'Pierwszy Europejczyk, a jego ojczyzna. Liudprand z Cremony i Królestwo Italii', in Sławomir Gawlas and Paweł Żmudzki (eds.), Symboliczne i realne podstawy tożsamości społecznej w średniowieczu, forthcoming.

${ }^{80}$ Antapodosis, IV.32.

81 “... vestimentis omnibus eam exuite, ne alicubi super se possit latere", Antapodosis, IV.12; Chiesa, 103; Squatriti, 148.

82 "... turpe facinus atque inauditum", Antapodosis, IV.12; Chiesa, 103; Squatriti, 148.

${ }^{83}$ Antapodosis, IV.23, 34.

${ }^{84}$ Chronicon Salernitanum, c. 76, pp. 73-5. 
of showing naked legs was not only improper but it also shamed her. Pieniądz notes that the Chronicon story shows the tyranny of power. The spectacle later on became the reason for Sikard's fall: he was killed by Adelchis in revenge for the apparent mistreatment of his wife. Her shame was, clearly, also his own. ${ }^{85}$ We moreover need to note that in the barbarians' laws (for example, Liutprand's) there was a strong opposition towards female nudity. There were many laws proscribing the stripping of women, with punishments imposed on those guilty of the crime. This in a way shows (as will become even more apparent) that those who made Willa naked were breaking the law. .6

Pieniądz further elaborates on the Liudprand tale under discussion. For her, the reaction of the people - the nobles who turned their sight away from Willa not to see her naked - meant that they wanted to avoid being ashamed by the view. It is clear that seeing her in nude would have caused them to lose honour as well. ${ }^{87}$ In Pieniądz's interpretation, Willa's nudity had a double meaning. First, it was a symbol of the attack on the innocent. By disrobing her, the soldiers were guilty of a crime against her body. But subsequently, the hidden belt showed that she was impure. Instead of retaining her status of a victim, she became a guilty sinner. Nevertheless, for Pieniądz, Liudprand puts the blame not only on the woman but also on the king. Their greed was behind their wrongful actions. But even in this interpretation it is clear that the stronger attack is at Hugh. Willa was in his control and he had full power over her and her body; thus, he could order the strip search. His act was targeted not only against the poor woman but also at her husband, who was the king's brother. ${ }^{88}$

85 Pieniądz, 'Kobieta', 412.

${ }^{86}$ Tyszka, 'Sexual Violence', 17-20. It is interesting to note one paragraph from Liutprand's law. There is a story of a man who stole the clothes of a woman bathing in a river. She was thus seen by those who were walking by as indecent (they figured she was purposefully naked in that situation) and was forced to walk naked home. Later on, the statement follows: "cui talem turpitudinem fecit", Liutprandi Leges 135 (MGH Leges 4, p. 166). In describing Willa’s situation, Liudprand says he has to "describe this most sordid deed" ("uno turpissimo descripto"); Antapodosis, IV.11; Chiesa, 103; Squatriti, 148.

${ }^{87}$ Not to mention that by avoiding this, they could also escape the possible revenge of Willa's relatives and of her husband's; Pieniądz, 'Kobieta', 418.

${ }^{88}$ Ibidem, 418-9. 
Thus, in the end, through Hugh's attack on Willa and her losing the status, Boso was shamed and denoted as weakling. ${ }^{89}$

Some of the aspects in Pieniądz's interpretation are hard to agree with. In her view, since Willa had dealt to an extent with the conspiracy against Hugh, her passive character during the whole shameful scene was meant by Liudprand to put her again in the proper place for woman. Her acts were apparently wrong when she involved herself in politics, and then she was punished exactly for that and, in the end, resumed her original position. ${ }^{90}$ In my view, the situation was quite different. Willa being active was not the reason for writing the story. The whole scene was only a means of attack and nowhere does Liudprand chastise her for being politically active.

Both the story of the wife saving her husband from castration and the one of Willa's belt appear in the beginning of Book 4 of Antapodosis. There is coincidence in tales of crossing the boundaries of proper behaviour appear there. Book 4 begins with the description of the Italian kingdom as a place of misfortune, ruled by a failed king and his futile attempts at acting properly. Hugh of Arles wants to conquer Rome but is unable to take it from the strong grasp of Alberic. Moreover, all Hugh's attempts imply actions that are a far cry from the decent behaviour expected of a ruler. First, he wants to use his daughter and, by wedding her to Alberic, to gain control over the city. Next, he attacks people living around the city. He is ruthless and at the same time he never actually attempts to attack Alberic, but instead goes after the innocent. Such is the background of the two Liudprand's jokes. They are followed by a description of how Hugh mistreated his newlywed wife, a widow of King Rudolph of Burgundy. Soon after the marriage, he began to indulge with concubines and, to make matters worse, Liudprand adds that they were not faithful to him. Instead, they had many other lovers, so it is impossible to say who were the fathers of their children..$^{91}$

This marks one half of the book, the other half covering the affairs of the Ottonian kingdom. The glory of Henry the Fowler and his son and successor, Otto, is presented. The text shows the second Liudolfing on the throne, as a glorious king, who always acts in a proper

\footnotetext{
${ }^{89}$ Ibidem, 423-4.

90 Ibidem, 420.

${ }^{91}$ Antapodosis, IV.13-4.
} 
fashion. Otto not only wins the battle against his enemies through prayer $^{92}$ but is also able to show mercy to his brother, who previously fought against him. ${ }^{93}$ Therefore, Liudprand's jokes are an element of a longer narrative, which aims to show that the Italian kingdom is a place where there is no good. In this narrative, men are evil, kings are failures, and more so, the victims of their evil actions are innocent. Women are among the latter, like Bertha, widow of Rudolph, and later Hugh's wife.

Balzaretti is right when he observes that the story about the wife and the soldier is funny because it is gendered (otherwise, there would have actually been no basis for the tale), but while Liudprand presents us a gallery of villainous women (it is tempting to write Willainous!) and uses sexually-oriented attacks to show them in a bad light, there is clearly more than that in his chronicle. The wife of the soldier is shown not only as a positive character, but is presented as stronger, wiser and having something we could call a better sense of comedy. The tale of the wife and the husband is, on the one hand, an anti-Byzantine attack making use of eunuchs; on the other, it is a part of historical satire that Liudprand wrote. It is neither an attack on women nor a portrait showing them in a bad light.

The tale about Willa and the belt is somewhat different, and yet similar. While its main layer presents the easy joke (and I agree at this point), aimed at humiliating a woman, to cause a smile on the reader's face is not its only purpose. Liudprand wants his readers to absorb his political opinions - and to do so, he shares with them jokes and tales. There are many different women appearing throughout Antapodosis. Some are almost holy ones, like Mathilda, ${ }^{94}$ some treated with cruelty by a husband, or even such who rule pretty big territories. All those belt tales and penis jokes are but a part of a more complex image that is present in Andapodosis. In parallel, these stories make Liudprand a variegated author whose works would not be studied nowadays with such fascination by the historians had they not been made part of his oeuvre.

proofread Tristan Korecki

92 Ibidem, IV.24.

${ }^{93}$ Ibidem, IV.35.

${ }^{94}$ Ibidem, IV.15. 


\section{SELECTED BIBLIOGRAPHY}

\section{Primary Sources}

Liudprand, Liudprand de Crémone: oeuvres, trans. François Bougard (Sources d'histoire médiévale, 41, Paris, 2015).

Liudprand of Cremona, The complete works of Liudprand of Cremona, trans. Paolo Squatriti (Washington, DC, 2007).

Liudprandus Cremonensis, Opera omnia, ed. Paolo Chiesa (Corpus Christianorum, Continuatio Mediaevalis, 156, Turnhout, 1998).

Liudprand von Cremona, Die Werke Luidprands von Cremona, ed. by Joseph Becker (Monumenta Germaniae Historica Scriptores rerum germanicarum in usum scholarum, 41, Hannover and Leipzig, 1915).

Liutprando, Antapodosis, trans. Paolo Chiesa (Scrittori greci e latini, Milano, 2015).

\section{Secondary Sources}

Atkinson Clarissa W., Oldest Vocation: Christian Motherhood in the Middle Ages (Ithaca, NY, 1994).

Balzaretti Ross, 'Liutprand of Cremona's Sense of Humour', in Guy Halsall (ed.), Humour, history and politics in late antiquity and the early Middle Ages (Cambridge and New York, 2002), 114-28.

Balzaretti Ross, 'Men and sex in tenth-century Italy', in Dawn M. Hadley (ed.), Masculinity in medieval Europe (London and New York, 1999), 143-59.

Buc Philippe, 'Italian Hussies and German Matrons. Liutprand of Cremona on Dynastic Legitimation', Frühmittelalterliche Studien, xxix (1995), 207-25.

Grabowski Antoni, 'Ostatnie studia o Liudprandzie z Cremony', Studia Źródtoznawcze, li (2013), 93-103.

La Rocca Cristina, 'Liutprando da Cremona e il paradigma femminile di dissoluzione dei Carolingi', in eadem (ed.), Agire da donna: modelli e pratiche di rappresentazione (secoli VI-X) (Turnhout, 2006), 291-307.

Pieniądz Aneta, 'Kobieta, honor i polityka we wczesnym średniowieczu', in Agnieszka Bartoszewicz et al. (eds.), Świat średniowiecza: studia ofiarowane Profesorowi Henrykowi Samsonowiczowi (Warszawa, 2010), 408-24.

Pieniądz Aneta, 'Wokół "Antapodosis" Liutpranda z Cremony', in Stanisław Rosik and Przemysław Wiszewski (eds.), Cor hominis: wielkie namiętności $w$ dziejach, źródtach $i$ studiach nad przeszłościa (Wrocław, 2007), 29-35.

Sivo Vito, 'Studi recenti su Liutprando di Cremona', Quaderni medievali, 44 (1997), 214-25.

Skinner Patricia, "'The light of my eyes": medieval motherhood in the Mediterranean', Women's History Review, vi, 3 (1997), 391-410.

Sutherland Jon N., Liudprand of Cremona, bishop, diplomat, historian: studies of the man and his age (Biblioteca degli 'Studi medievali', 14, Spoleto, 1988).

Tyszka Przemysław, The Human Body in Barbarian Laws, c. 500-c. 800: the corpus hominis as a cultural category, trans. Guy R. Torr (Frankfurt am Main and New York, 2014).

Antoni T. Grabowski - medieval history; post-doctoral researcher; e-mail: antoni@grabowscy.net.pl 